\section{Stress-strain behavior of}

\section{high porous zirconia ceramic}

IRINA N. SEVOSTIANOVA - Institute of Strength Physics and Materials Science,

SB RAS, Tomsk, Russia " sevir@ispms.ru

TATIANA Yu. SABLINA - Institute of Strength Physics and Materials Science,

SB RAS, Tomsk, Russia • sabtat@ispms.ru

SERGE N. KULKOV - Institute of Strength Physics and Materials Science,

SB RAS, Tomsk, Russia • kulkov@ms.tsc.ru

MoHAmmed TIHTIH - Institute of Ceramics and Polymer Engineering,

University of Miskolc, Hungary • medtihtih@gmail.com

LÁszLó A. GÖMZE - Institute of Ceramics and Polymer Engineering,

University of Miskolc, Hungary, IGREX Engineering Service Ltd · femgomze@uni-miskolc.hu

Érkezett: 2021. 06. 03. - Received: 03. 06. 2021. - https://doi.org/10.14382/epitoanyag-jsbcm.2021.23

\section{Annotation}

In this work, we studied the deformation behavior of $\mathrm{ZrO}_{2}$ ceramics stabilized with 5.5 wt.\% $\mathrm{Y}_{2} \mathrm{O}_{3}$ with a porosity of $4-42 \%$ during diametral compression tests ("Brazilian" test). It has been shown that with an increase in porosity from 4 to $42 \%$, the ultimate tensile strength in diametral compression decreases from 115 to $9 \mathrm{MPa}$. The ultimate strain before fracture decreases from 1 to $0.8 \%$. The effective modulus also decreases with increasing of porosity. The analysis of the "stress-strain" curves showed that the deformation behavior of ceramics is influenced by both the volume and the morphology of the pore space. It been shown that two strain exponent were observed, which indicate a change of deformation mechanism of the ceramic during loading. X-ray diffraction analysis carried out from the front surface of fracture fragments of samples with porosities of 4,17 , and $42 \%$ showed that in these materials microstructural parameters such us the size of the coherently diffracting domains of the tetragonal phase and lattice microdistortion changes in comparison with the initial state after sintering. These materials microstructural parameters are changes non-uniformly, which indicate the inhomogeneity of the deformation of this brittle material during compression.

Keywords: ceramics, lattice microdistortion, porous, stress, zirconia

Kulcsszavak: kerámia, rácsos mikrotorzítás, porózus, feszültség, cirkónia
Irina N. SEVOSTYANOVA

PhD Education: 1987: Tomsk Polytechnic Universityengineer.1993-1996: Institute of Strength Physics and Materials Science of the Russian Academy of Sciences in Tomsk - PhD student. 2001: PhD degree from the Institute of Strength Physics and Materials Science of the Russian Academy of Sciences in Tomsk. Field of research: Structure and mechanical property of porous ceramics based zirconia and alumina.

Tatiana Yu. SABLINA has PhD Education since 1989 at present she is working at the Tomsk State University and Institute of Strength Physics and Materials Science of the Russian Academy of Sciences in Tomsk.

Sergei N. KULKOV is professor at the Tomsk State University and head of Department of Ceramics in the Institute of Strength Physics and Materials Science of the Russian Academy of Science since 1989 His research works are represented in 5 books, more than 150 articles, 18 patents and many nternational Symposiums and Conferences. At present he is head of department "Theory of Strength and Mechanic of Solids", member of "The American Ceramic Society” of "The APMI International" and the DYM AT Society (France).

Mohammed TIHTIH Is a lecturer in the Sidi Mohamed Ben abdellah University, Morocco, he graduated from Faculty of sciences Dhar El Mahraz, Fez, Morocco, Department of Physics, for the time being, he is a PhD student in the University of Miskolc, Institute of Ceramics and Polymer Engineering, under supervision of Prof. L. A. Gömze.

László A. GÖMZE

\section{Introduction}

The study of the deformation and fracture behavior in a brittle porous material under its mechanical loading has recently attracted considerable attention of researchers [1-5]. These studies are important for estimation of the fundamental base for the synthesis of new composite materials which can be used for extremely loaded conditions, as biomaterials, filters, and soundproof materials for various anti-noise devices. Mechanical strength is a key parameter for many ceramic applications where porous ceramic parts are subjected to compression, bending, tension and shear [6]. Also, these data can be very useful for the model study of mechanical properties and processes of fracture of rocks [7]. Today, most mechanical tests have been carried out on dense materials with a uniform structure. The processes of deformation and fracture of porous ceramic materials are being actively investigated, and in literature there are some results of measuring of elastic constants with different porosity [8]. The effects of nonlinear elasticity under mechanical loading of porous ceramics based on zirconia are described in [9]. It has been determined that deformation of materials with a complex internal structure, local strains due to relative displacements and deformations of its structural components play a significant role, which noticeably changes the elastic characteristics of materials. In the literature, this behavior is discussed in terms of the is establisher and professor of the Department of Ceramics and Silicate Engineering in the University of Miskolc, Hungary. He is author or coauthor of 2 patents, 6 books and more than 300 scientific papers. Recently, he is the chair of the International Organization Board of ic-cmtp6 the $6^{\text {th }}$ International Conference on Competitive Materials and Technological Processes and ecsiliconf2 the $2^{\text {nd }}$ European Conference on Silicon and Silica Based Materials.

transition from brittle fracture to quasi-plastic [10-13]. This was previously observed in the case of concrete [14], ferroelectric ceramics [15], and a glass or ceramic matrix composites [16]. Recently, a similar deformation behavior was observed for uniaxial compression tests of porous ceramics [17-18], as well as in bending tests of refractory materials [19]. At the same time, works in which other schemes of loading brittle materials are used are not enough. So the performance of direct tests for uniaxial tension of brittle materials is associated with the technical problem of applying tensile axial forces to the sample [20]. To determine the tensile strength of brittle materials, an indirect method for determining the tensile strength of the material, the so-called "Brazilian test", is successfully used, when tensile stresses are formed in the center of the sample [21-23]. The particular qualities of the stress-strain state of the samples during the Brazilian test continue to attract the interest of many researchers from the moment of its proposal. Investigations are carried out by various experimental [22-24] and numerical methods [25-28]. Nevertheless, investigations of the deformation behavior of ceramic materials based on 
zirconia in a wide range of changes in pore sizes and pore volume have been insufficiently conducted.

The aim of this work was to study the stress-strain behavior of porous zirconia ceramics with a wide range of porosity during diametral compression tests.

\section{Materials and methods}

To obtain experimental samples, we used zirconia powder $\left(\mathrm{ZrO}_{2}\right)$ stabilized with $5.5 \mathrm{wt} \%$ yttrium oxide $\left(\mathrm{Y}_{2} \mathrm{O}_{3}\right)$. The study of the $\mathrm{ZrO}_{2}-5.5 \mathrm{wt} \% \mathrm{Y}_{2} \mathrm{O}_{3}$ powder $\left(\mathrm{ZrO}_{2}(\mathrm{Y})\right)$ was carried out on a VEGA Tescan 3 SBH scanning electron microscope. The particle size distribution of the powder, including agglomerates, and a typical SEM image of the powder are shown in Fig. 1.

The powder is a finely dispersed mixture of agglomerated particles of irregular shape. The particle size of the powder varies from 0.1 to $2 \mu \mathrm{m}$, and the fraction of particles up to $0.5 \mu \mathrm{m}$ is about $70 \%$. The specific surface area of the powder $\left(\mathrm{S}_{\mathrm{sp}}\right)$, measured on a SORBI-4.1 device, by low-temperature nitrogen adsorption by the 4-point BET method [29] is $8.05 \pm$ $0.085 \mathrm{~m}^{2} / \mathrm{g}$. According to the results of X-ray phase analysis, the powder consists of tetragonal and monoclinic phases of zirconia. The content of the monoclinic phase in the powder is $44 \%$.

Experimental samples traditional methods of powder metallurgy were prepared. The plasticized (5\% carboxymethyl cellulose (CMC) aqueous solution) powder was cold isostatic compaction with a hydraulic press under a pressure of $50 \mathrm{MPa}$ and followed low-temperature annealing of the compacts to remove the binder was carried out at a temperature of 1100 ${ }^{\circ} \mathrm{C}$ with a heating rate of $1.5^{\circ} \mathrm{C} / \mathrm{min}$ in the $\mathrm{MgO}$ powder fill. The final sintering of the samples was carried out in a hightemperature air muffle furnace LHT "Nabertherm" according to the modes presented in Table 1. To obtain samples with different porosities, the sintering temperature and isothermal holding time were varied.

The pore structure of the sintered ceramics was studied on polished surfaces using VEGA Tescan $3 \mathrm{SBH}$ scanning electron microscope. The determination of the average pore size and their size distribution was carried out using the ImageJ program; in this case, at least three images of the structure and at least 1000 measurements were used. The ratio of pores size smaller than $30 \mu \mathrm{m}$ and over $30 \mu \mathrm{m}$ of all investigated ceramics was calculated by the methods of stereometric metallography [30]. The two-dimensional distribution of pores by size was transformed into a three-dimensional distribution using the basic stereometric equation of Saltykov [30]. Zirconia phase fractions were quantified on sintered and fractured specimens using the X-ray diffraction analysis (XRD). XRD spectra were collected over a $2 \theta$ range between $20^{\circ}$ and $80^{\circ}$ using a powder diffractometer equipped with a $\mathrm{Cu} \mathrm{X}$-ray source with a step size of $0.05^{\circ}$ with statistical accuracy better $3 \%$. XRD line profile analysis was used to determine of the size of the coherently diffracting domain (D) and crystal lattice microdistortion $\left(\left\langle\varepsilon^{2}\right\rangle^{1 / 2}\right)$ of tetragonal phase of zirconia. The size of the coherently diffracting domains (sCDDs) was calculated by the Scherrer equation [31] for the lines (111) and crystal lattice microdistortion was calculated according to the Stokes - Wilson equation [32] for the lines (004).

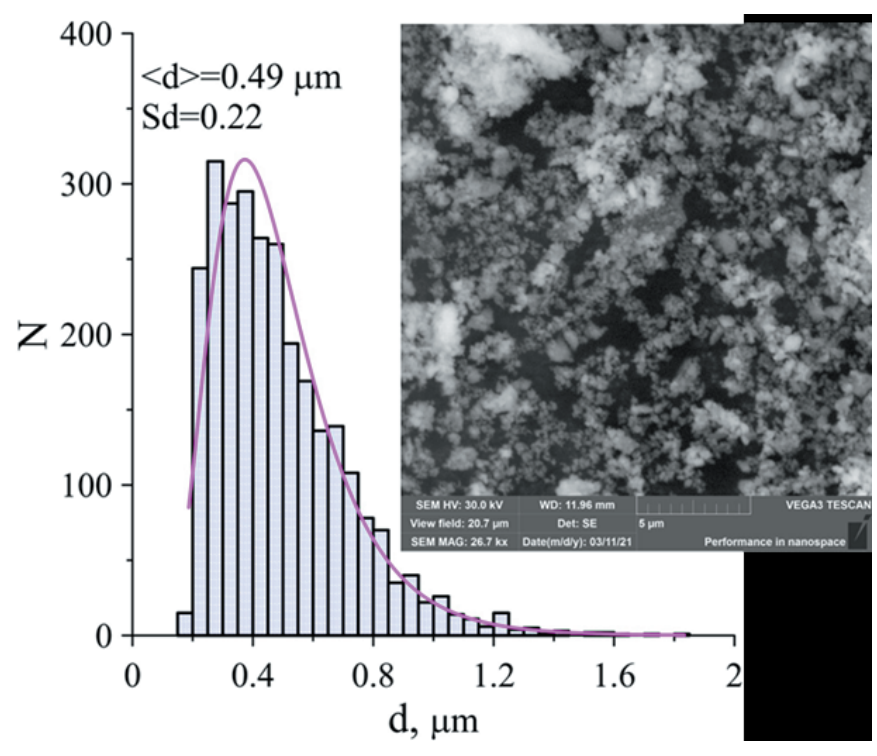

Fig. 1 Particle size distribution of zirconia powder. The insets show the SEM image of the powders

1. ábra A cirkóniumpor részecskeméret-eloszlása. A porok SEM felvétele

The porosity and phase composition of the specimens before diametral compression tests (in the initial state), depending on the sintering conditions, are given in Table 1.

\begin{tabular}{|c|c|c|c|}
\hline $\begin{array}{l}\text { Sample } \\
\text { number }\end{array}$ & $\begin{array}{l}\text { Sintering } \\
\text { conditions, } \\
\mathbf{T},{ }^{\circ} \mathbf{C} ; \mathbf{\tau}, \mathbf{h}\end{array}$ & $\begin{array}{l}\text { Porosity, } \\
\%\end{array}$ & Phase composition, \% \\
\hline 1 & $\begin{array}{c}\mathrm{T}=1600^{\circ} \mathrm{C} \\
\mathrm{T}=1 \mathrm{~h}\end{array}$ & 4 & $\begin{array}{l}\mathrm{ZrO}_{2}\left(t^{*}\right)-80 \\
\mathrm{ZrO}_{2}\left(c^{* *}\right)-20\end{array}$ \\
\hline 2 & $\begin{array}{c}\mathrm{T}=1500^{\circ} \mathrm{C} \\
\mathrm{T}=1 \mathrm{~h}\end{array}$ & 17 & $\begin{array}{l}\mathrm{ZrO}_{2}(t)-80 \\
\mathrm{ZrO}_{2}(\mathrm{c})-20\end{array}$ \\
\hline 3 & $\begin{array}{c}\mathrm{T}=1400^{\circ} \mathrm{C}, \\
\mathrm{T}=3 \mathrm{~h}\end{array}$ & 29 & $\begin{array}{c}\mathrm{ZrO}_{2}(\mathrm{t})-88 \\
\mathrm{ZrO}_{2}(\mathrm{c})-9 \\
\mathrm{ZrO}_{2}(\mathrm{~m} * * *)-\text { trace (less 3) }\end{array}$ \\
\hline 4 & $\begin{array}{c}\mathrm{T}_{\text {спек }}=1400^{\circ} \mathrm{C}, \\
\mathrm{T}=2 \mathrm{~h}\end{array}$ & 33 & $\begin{array}{c}\mathrm{ZrO}_{2}(t)-93 \\
\mathrm{ZrO}_{2}(\mathrm{c})-6 \\
\mathrm{ZrO}_{2}(m)-\text { trace (less 3) }\end{array}$ \\
\hline 5 & $\begin{array}{c}\mathrm{T}_{\text {спек }}=1350^{\circ} \mathrm{C}, \\
\tau=1 \mathrm{~h}\end{array}$ & 42 & $\begin{array}{c}\mathrm{ZrO}_{2}(t)-95 \\
\mathrm{ZrO}_{2}(c)-4 \\
\mathrm{ZrO}_{2}(m)-\text { trace (less 3) }\end{array}$ \\
\hline
\end{tabular}

$t^{\star}$ - tetragonal phase $\mathrm{ZrO}_{2}$;

$\mathrm{c}^{* *}$ - cubic phase $\mathrm{ZrO}_{2}$;

$m * * *$ - monoclinic phase $\mathrm{ZrO}_{2}$

Table 1 Porosity and phase composition of $\mathrm{ZrO}_{2}(Y)$ ceramic samples depending on sintering conditions

1. táblázat $\mathrm{ZrO}_{2}(Y)$ kerámiaminták porozitása és fázisösszetétele a szinterelési körülményektöl függően

The phase composition of ceramic samples sintered at temperatures of 1500 and $1600^{\circ} \mathrm{C}$ is represented by hightemperature tetragonal and cubic phases of zirconia in a ratio of 80:20, respectively. With a decrease of the sintering temperature, the ratio of the tetragonal and cubic phases changes, with a decrease in the content of the cubic phase and the appearance of traces of the monoclinic $\mathrm{ZrO}_{2}$ phase, Table 1.

Diametral compression tests (the Brazilian test) of ceramic samples with a diameter of $27.5 \pm 0.3 \mathrm{~mm}$ and a height of $11.3 \pm 0.2 \mathrm{~mm}$ were carried out on a universal testing machine "Instron" at a loading rate of $0.1 \mathrm{~mm} / \mathrm{min}$ with automatic recording of the loading diagram "load - displacement" taking 
into account the rigidity of the loading system. The calculation of stresses was performed according to [33].

\section{Results and discussion}

The pore structure of $\mathrm{ZrO}_{2}(\mathrm{Y})$ ceramic samples with different porosity and pore space morphology is shown in Fig. 2. Interparticle isolated porosity of ceramics with a porosity of $4 \%$ (sample 1 , table 1 ), is observed. The average pores size is $\approx 4 \mu \mathrm{m}$ and the maximum pores size does not exceed $30 \mu \mathrm{m}$, Fig. 2 (a). Two types of pores and a bimodal pore size distribution in the structure of ceramic samples with a porosity of $17 \%$ and higher (samples $2-5$, table 1 ), are observed, Fig. 2 (b). In addition to interparticle porosity (1 $30 \mu \mathrm{m})$, the ceramic contains large interagglomerate pores of irregular shape with sizes of $30-80 \mu \mathrm{m}$, the number of which increases with increasing porosity.
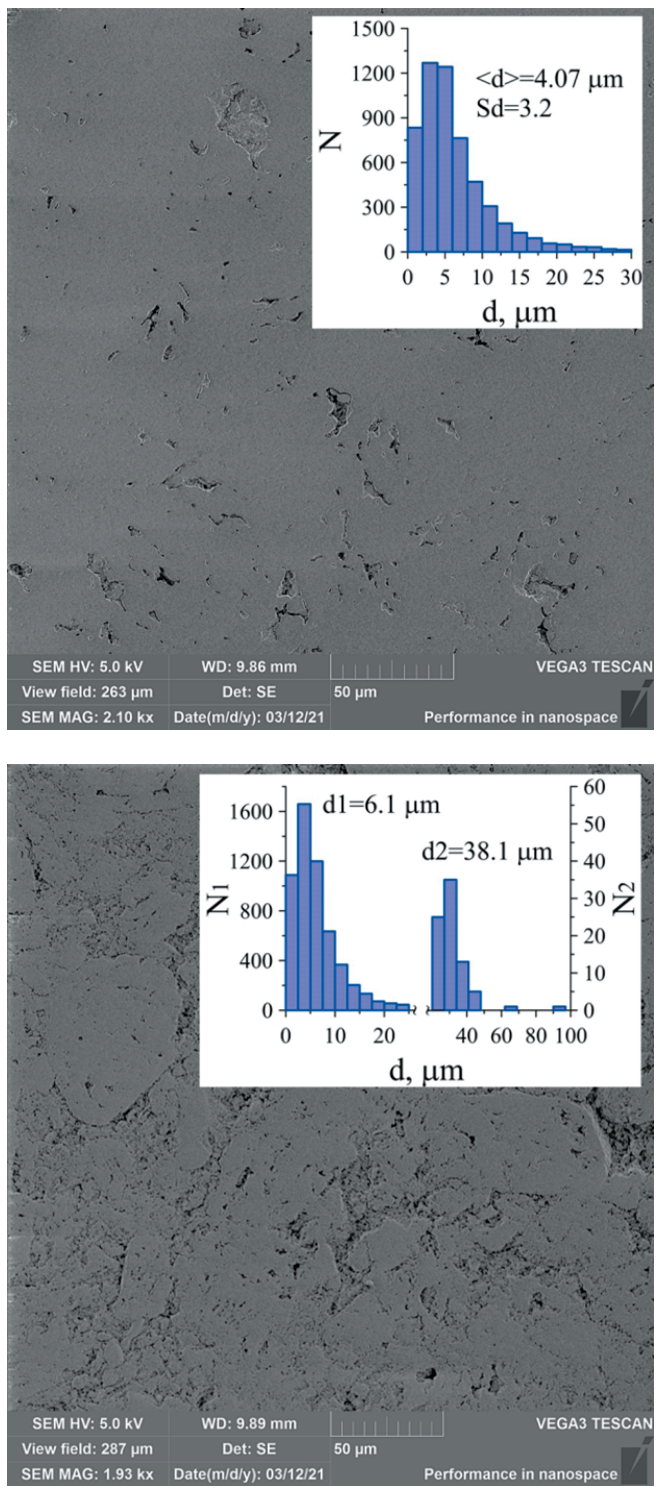

Fig. 2 Typical image of the porous structure: (a) - ceramic with porosity 4\%; (b) - ceramic with porosity $42 \%$. The insets show the pore size distribution of ceramics with different pore space morphology

2. ábra A porózus szerkezet tipikus képe: (a) - 4\%-os porozitású kerámia; (b) 42\%-os porozitású kerámia. A különbözö pórustér morfológiájú kerámiák pórusméret-eloszlása
The changes in the average pore size of the studied ceramics are shown in Table 2. It can be seen that with the porosity of the samples increasing, the average pore size $(<d>)$ increases from 4 to $6.4 \mu \mathrm{m}$. In this case, with an increase in the average pore size, the size dispersion of powders also grows. Also, with an increase in porosity, an increase of the average size of both small $<\mathrm{d} 1>$ and large pores $<\mathrm{d} 2>$ is observed. From the histogram shown in Fig. 2 (a), it can be seen that in the sample with a porosity of $4 \%$, pores larger than $30 \mu \mathrm{m}$ are absent. In samples with a porosity of $17 \%$ and higher, the pore volume with sizes of pores larger than $30 \mu \mathrm{m}$ increases with increasing porosity but does not exceed 10 vol.\%.

\begin{tabular}{|c|c|c|c|c|c|c|c|}
\hline $\begin{array}{l}\text { Sample } \\
\text { number }\end{array}$ & $\begin{array}{l}\text { Porosity, } \\
\quad \%\end{array}$ & $\begin{array}{l}<d> \pm \\
0.2 \mu \mathrm{m}\end{array}$ & $S d$ & $\begin{array}{l}<d 1> \pm \\
0.2 \mu \mathrm{m}\end{array}$ & $\begin{array}{c}<d 2> \pm \\
1 \mu \mathrm{m}\end{array}$ & $\begin{array}{c}\mathbf{V}_{\text {por }} \\
\text { (Size of } \\
\text { pores } \\
<30 \mu \mathrm{m} \text { ), } \\
\%\end{array}$ & 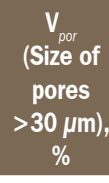 \\
\hline 1 & 4 & 4.07 & 3.2 & - & - & 100 & - \\
\hline 2 & 17 & 4.95 & 4.5 & 3.8 & 28.3 & 97 & 3 \\
\hline 3 & 29 & 5.3 & 4.7 & 4.74 & 32.4 & 95 & 5 \\
\hline 4 & 33 & 5.33 & 5.6 & 4.9 & 39 & 90 & 10 \\
\hline 5 & 42 & 6.4 & 5.8 & 6.1 & 38.1 & 93 & 7 \\
\hline $\begin{array}{r}\text { Table } 2 \\
\text { 2. tábláza }\end{array}$ & $\begin{array}{l}\text { Change } \\
\text { A kerám } \\
\text { függően }\end{array}$ & $\begin{array}{l}\text { the aver } \\
\text { próbate }\end{array}$ & $\begin{array}{l}\text { pore } \\
\text { cátla }\end{array}$ & $\begin{array}{l}\text { ze in cera } \\
\text { spórusm }\end{array}$ & $\begin{array}{l}\text { cs with di } \\
\text { tének vált }\end{array}$ & $\begin{array}{l}\text { rent por } \\
\text { ása a pot }\end{array}$ & \\
\hline
\end{tabular}

Fig. 3 (a) shows the "stress-strain" curves during diametral compression tests of ceramic specimens with different porosities. The diametral compression experiments showed that the behavior of all specimens upon loading was typical as for brittle materials. An analysis of the deformation curves showed that for samples with porosities of 4 and $17 \%$ were deformed elastically up to its fracture. The deformation curves of specimens with a higher porosity are showing a deviation from linearity before their fracture. The deviation from linearity of specimens with a porosity of $27 \%$ and higher was observed in other works [ 8 , 12] for other loading schemes of porous ceramics and may be associated with the appearance and accumulation of defects in the form of microcracks during loading, which is representative of the quasi-brittle fracture of porous ceramic materials.

Re-plotting of the « $\sigma-\varepsilon »$ dependences in double logarithmic coordinates $\operatorname{Ln}\left(\sigma / \sigma_{0}\right)-\operatorname{Ln}(\varepsilon)$, they were transformed into two parts, which can be approximated by linear functions with varying inclination to the $\mathrm{X}$-axis $(\operatorname{Ln}(\varepsilon))$, and therefore, with different exponent of strain hardening $\mathrm{n}$ of the Hollomon equation [34]. The inset in Fig. 3 (a) shows a representative curve with different exponents of strain hardening $\mathrm{n} 1$ and $\mathrm{n} 2$. The exponent of strain hardening $\mathrm{n} 1$, calculated from linear functions, increase from 1.45 to 1.7 with an increase of samples porosity from 4 to $33 \%$ and in a sample with a porosity of $42 \%$, a decrease in $\mathrm{n} 1$ is observed, Fig. 3 (b). The exponent of strain hardening $\mathrm{n} 2$ practically does not change with an increase of the porosity of the samples and is equal to $\sim 1.2$.

It should be noted that on all dependences « $\operatorname{Ln}(\sigma)-\operatorname{Ln}(\varepsilon)$ » the strain exponents $n$ are large 1 , which probably corresponds to the nonlinear elastic behavior of ceramics under load with a change of porosity. In this case, the change in the angle of inclination of the linear sections on the curves « $\operatorname{Ln}(\sigma)-\operatorname{Ln}(\varepsilon)$ » 
may indicate a change in the mechanism of deformation of the ceramic during loading. The change in the slope on the curves for ceramics with porosities of 4 and $17 \%$ can be associated with microcracking caused by the tetragonal-monoclinic phase transformation during loading. On the fracture surface of samples with porosity of 4 and $17 \%$ according to the X-ray phase analysis the formation of a monoclinic phase with a volume content of $30 \%$ and $12 \%$, respectively, are observed.
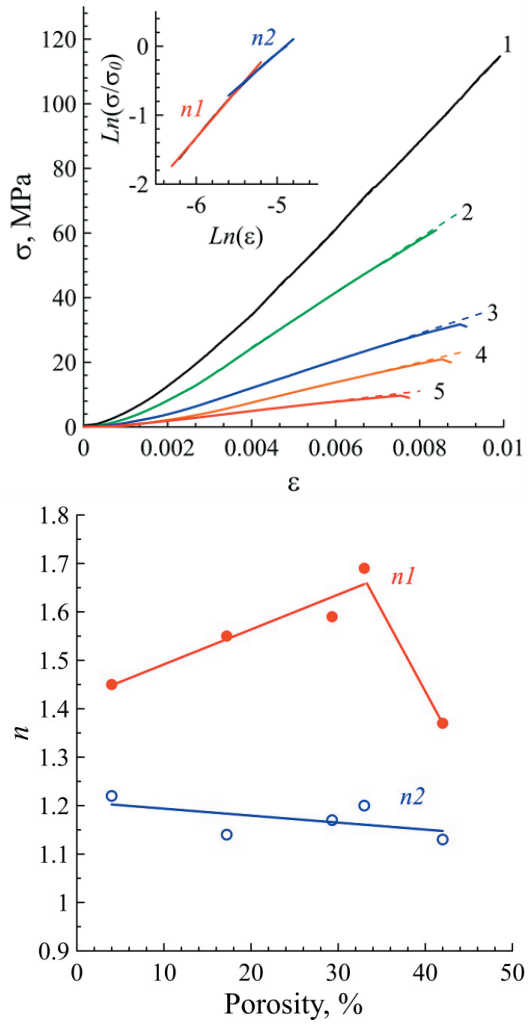

Fig. 3 Deformation curves of $\mathrm{ZrO}_{2}(Y)$ ceramic specimens with different porosity during diametral compression tests (a). At the curves, numbers indicate the sample numbers, according to Table 1. (The inset in Fig. 3 (a) shows the deformation curve with a porosity of $42 \%$ in the coordinates $L n(\sigma / \sigma)$ $\operatorname{Ln}(\varepsilon))$; Dependence of the exponents of strain hardening $n 1$ and $n 2$ vs the samples porosity $(b)$

3. ábra Különböző porozitású $\mathrm{ZrO}(Y)$ kerámia minták deformációs görbéi a diametrális kompressziós vizsgálatok során (a). A görbéknél a számok az 1. táblázat szerinti mintaszámokat jelölik. (A 3. ábra a) betétje a deformációs görbét 42\%-os porozitással mutatja az $\operatorname{Ln}\left(\sigma / \sigma_{\vartheta}\right)$ - Ln( $\left.(\varepsilon)\right)$ koordinátákban); Az $n 1$ és $n 2$ a terhelési keményedés kitevőinek függése a minták porozitásától (b)

The formation of microcracks in ceramics with a porosity of $29 \%$ and higher during deformation is caused by the fracture of bridges and lintels of the interpore frame. On the fracture surfaces of ceramics samples with a porosity of $29 \%$ and higher, no increase of the monoclinic phase was observed in comparison with the initial state.

The tensile strength $\left(\sigma_{t}\right)$ decreases with an increase of porosity, Fig. 4 (a). The change of $\sigma_{t}$ from porosity is well described by a power function with a high correlation coefficient $(\mathrm{R}=0.99)$.

Analysis of the change of the ultimate strain before fracture $(\varepsilon)$, obtained from the deformation curves « $\sigma-\varepsilon »($ Fig. $3(a))$, showed that the strain $(\varepsilon)$ decreases slightly from 1 to $0.8 \%$ with an increase of the samples porosity (curve 1, Fig. 4 (b)).

The effective modulus of elasticity $\left(\mathrm{E}_{\text {eff }}\right)$, calculated from the slope of the stress-strain curves are decreases with increasing samples porosity (curve 2, Fig. $4($ b)).
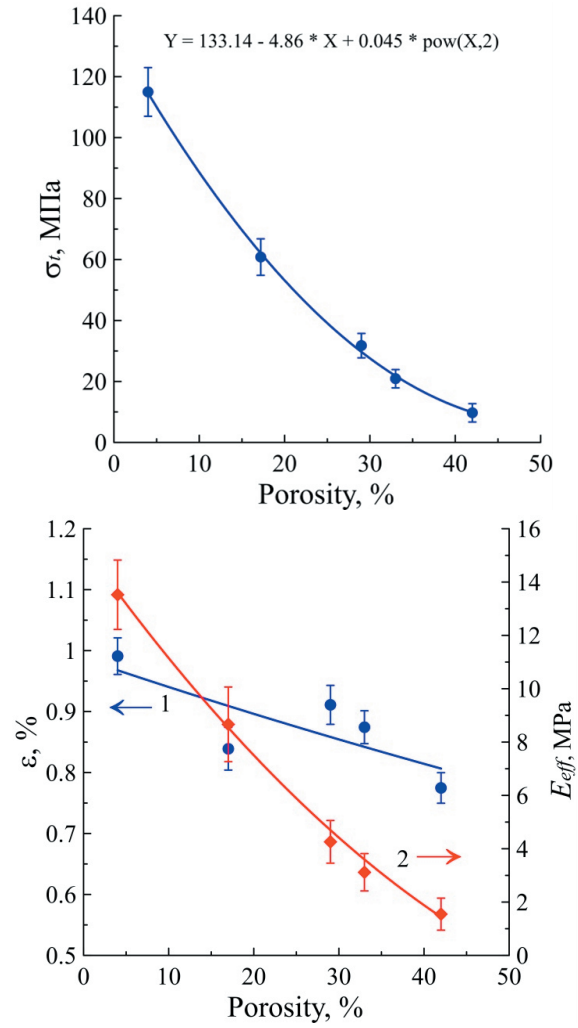

Fig. 4 Dependence of tensile strength vs samples porosity (a); Dependence of ultimate strain before fracture ( $\varepsilon$ ) (curve 1) and the effective modulus of elasticity $\left(E_{\text {eff }}\right)$ (curve 2) vs samples porosity $(b)$

4. ábra A szakitószilárdság függése a minták porozitásától (a); A törés elötti végsó fajlagos alakváltozás $(\varepsilon)$ (1. görbe) és az effektív rugalmassági modulus $\left(E_{e f f}\right)$ (2. görbe) függése a minták porozitásától (b)

After diametral compression tests of samples with porosity of 4,17 , and $42 \%$, X-ray diffraction analysis was carried out from the front surface of fracture fragments of the samples.

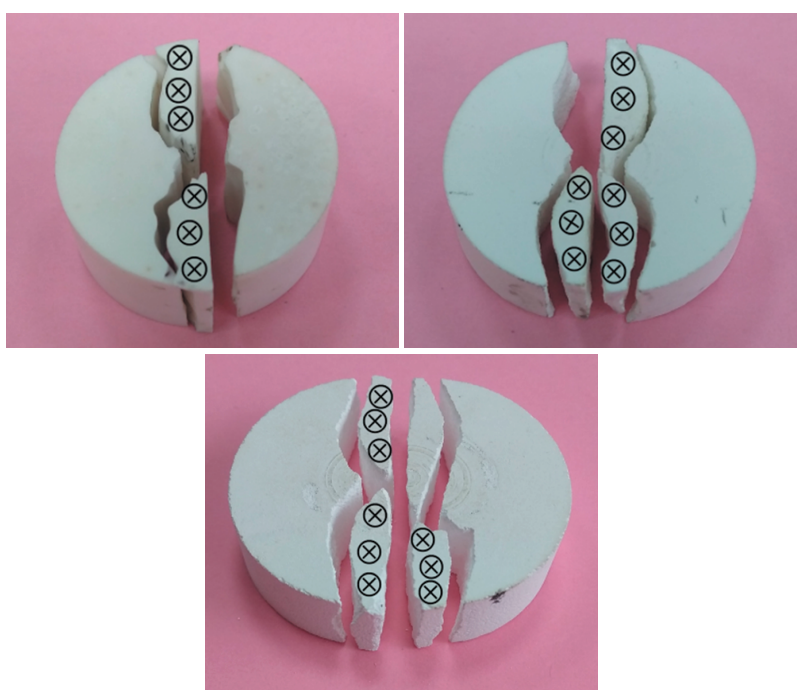

Fig. 5 Macrophotographs of samples with different porosity $(a-4 \% ; b-17 \% ; c$ $42 \%)$ after diametral compression tests with XRD schemes

5. ábra Különbözö porozitású minták makrofotói ( $a-4 \%$; $b-17 \%$; $c-42 \%)$ XRD sémákkal végzett diametrális kompressziós tesztek után

The size of the coherently diffracting domains and the crystal lattice microdistortion from different place of the fracture 
fragments are determined. X-ray diffraction analysis was carried out for the local points from fractured fragments along the loading axis during diametral compression tests, in the direction starting from the point of contact of the sample with the active platform of the testing machine towards the passive platform with a step of 2-3 $\mathrm{mm}$, the areas for X-ray studies for each point was approximately $4 \mathrm{~mm}^{2}$. Fig. $5(a, b, c)$ shows macro photographs of samples with different porosities after diametral compression tests with $\mathrm{X}$-ray diffraction analysis schemes.

The dependences of the size of the coherently diffracting domains and the crystal lattice microdistortion of samples with porosities of 4, 17, and $42 \%$ are shown in Fig. 6. It follows from the figure that for all samples with different porosity a dispersion both sizes of the CDD and crystal lattice microdistortion are decrease with increase a distance from the active platform of the testing machine and does not exceed $10 \%$. These data indicate the appearances of deformation inhomogeneity of porous ceramics under diametral compression along the compression axis.
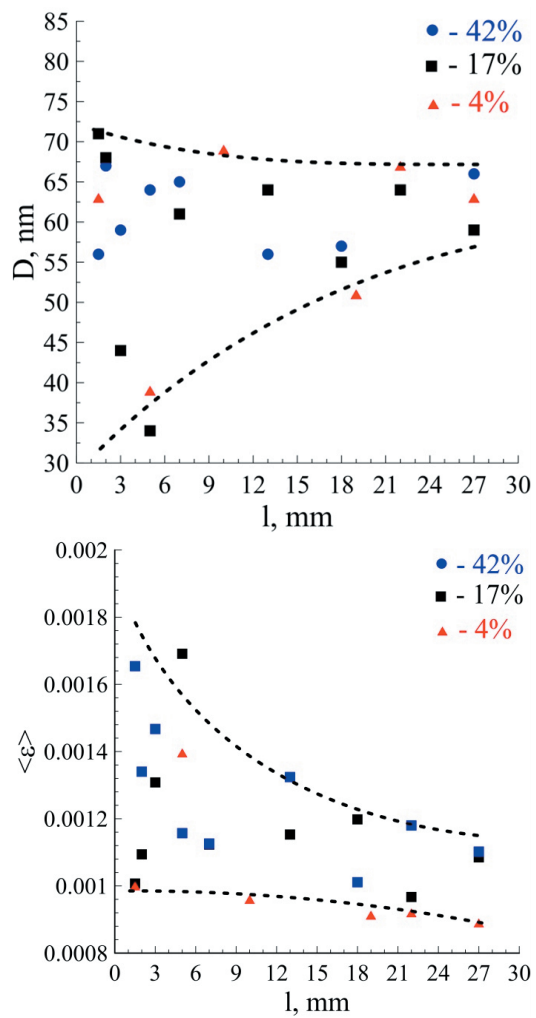

Fig. 6 Change of the size of the $C D D(a)$ and the crystal lattice microdistortions $(b)$ of fracture fragments of ceramic samples with porosity of 4, 17 and $42 \%$ after diametral compression tests. The start point (zero) is corresponds to the point of contact of the sample with the active platform of the testing machine, and last point $(30 \mathrm{~mm})$ is corresponding to the point of contact of the sample with the top (passive) platform of the testing machine

6. ábra A kerámiai minták 4, 17 és 42\% porozitású töretdarabjainak CDD méretének (a) és kristályrácsos mikrotorzulásának (b) változása a diametrális kompressziós vizsgálatok után. A kiindulási pont $(0 \mathrm{~mm})$ a minta és a tesztgép aktív platformjának érintkezésénél, az utolsó pont (30 mm) pedig a minta és a tesztelő gép felső (passziv) platformjának érintkezése

\section{Conclusions}

It has been shown that with an increase of the porosity of ceramic, there are a decrease in the ultimate tensile strength in diametral compression from 115 to $9 \mathrm{MPa}$ and the ultimate deformation to fracture. The effective modulus of elasticity calculated from the slope of the stress-strain curves also decreases with increasing of porosity.

It been shown that two strain exponent were observed, which indicate a change of deformation mechanism of the ceramic during loading. The decrease of $\mathrm{n} 2$ in ceramics with porosities of 4 and $17 \%$ is due to the phase transformation from the tetragonal to the monoclinic phase under the action of applied stresses, and in ceramics with porosity above $29 \%$, it is associated with the formation of multiple microcrack defects during deformation.

It has been shown that in these materials microstructural parameters - coherently diffracting domains of the tetragonal phase and the crystal lattice microdistortions, are changes non-uniformly, which indicate the inhomogeneity of the deformation of this brittle material during compression.

\section{Acknowledgments}

The work was performed according to the Government research assignment for ISPMS SB RAS, project FWRW2021-0005. The described article was carried out as part of the EFOP-3.6.1-16-00011 "Younger and Renewing University -Innovative Knowledge City - institutional development of the University of Miskolc aiming at intelligent specialisation" project implemented in the framework of the Széchenyi 2020 program.

\section{References}

[1] Anderson, T.L., (2017) Fracture mechanics: fundamentals and applications, CRC Press, 680 pp.

[2] Bažant, Z.P., Planas, J., (1998) Fracture and Size Effect in Concrete and Other Quasibrittle Materials, CRC Press, New York, 136 pp.

[3] Kaczmarek, M. Goueygou, M., (2006) Dependence of elastic properties of materials on their porosity: Review of models. Journal of Porous Media, 9 (4), pp. 335-355. https://doi.org/10.1615/JPorMedia.v9.i4.50

[4] Goldstein, R.V., Osipenko, N.M., 2019. About compression fracture. Physical Mesomechanics, 22 (6), pp. 439-455. https://doi.org/10.1134/S1029959919060018

[5] Ibrahim, J.F.M.., Gömze, L.A., Kotova, O.B., Shchemelinina, T.N., Shushkov, D.A., Ignatiev, G.V., Anchugova, E.M., (2019) The influence of composition, microstructure and firing temperature on the density, porosity, and shrinkage of new zeolite-alumina composite material. Építőanyag - JSBCM 70(4), pp.120-124. https://doi.org/10.14382/epitoanyag-jsbcm.2019.21

[6] Rice, R.W., (1989) Relation of tensile strength-porosity effects in ceramics to porosity dependence of Young's modulus and fracture energy, porosity character and grain size. Mater Sci Eng, A, 112, pp. 215-224.

[7] Junhong, Yu., Xinchun, Shang., (2019) Analysis of the influence of boundary pressure and friction on determining fracture toughness of shale using cracked Brazilian disc test. Engineering Fracture Mechanics, 212, pp. 57-69. https://doi.org/10.1016/j.engfracmech.2019.03.009

[8] Grigorev, M.V., Savchenko, N.L., Sablina, T.Yu., Kurovics, E., Sevostyanova, I.N., Buyakova, S.P., Gomze, L.A., Kulkov, S.N., (2018) Deformation and fracture of alumina ceramics with hierarchical porosity. Építőanyag JSBCM. 70(1), pp. 18-22.

https://doi.org/10.14382/epitoanyag-jsbcm.2018.4

[9] Kulkov, S.N., Maslovskii, V.I., Buyakova, S.P., Nikitin, D.S., (2002) The non-hooke's behavior of porous zirconia subjected to high-rate compressive deformation. Technical Physics, 47(3), pp. 320-324. https://doi.org/10.1134/1.14631212002

[10] Meille, S., Lombardi, M., Chevalier, J., Montanaro, L., (2012) Mechanical properties of porous ceramics in compression: On the transition between 
elastic, brittle, and cellular behavior. Journal of the European Ceramic Society, 32, pp. 3959-3967.

https://doi.org/10.1016/j.jeurceramsoc.2012.05.006

[11] Ohji, T., Fukushima, M., (2012) Macro-porous ceramics: processing and properties. Int. Mater.Rev., 57, pp. 115-131. https://doi.org/10.1179/1743280411Y.0000000006

[12] Savchenko, N.L., Sablina, T.Yu., Sevostyanova, I.N., Buyakova, S.P. Kulkov, S.N., (2016) Deformation and fracture of porous brittle materials under different loading schemes. Russian Physics Journal, 58(11), pp. 1544-1548. https://doi.org/10.1007/s11182-016-0680-4

[13] Šavija, B., Smith, G.E., Liu, D., Schlangen, E., Flewitt, P.E.J., (2019) Modelling of deformation and fracture for a model quasi-brittle material with controlled porosity: Synthetic versus real microstructure. Engineering Fracture Mechanics, 205, pp. 399-417. https://doi.org/10.1016/j.engfracmech.2018.11.008

[14] Bocca, P., Carpinteri, A., Valente, S., (1991) Mixed mode fracture of concrete. Int J. Sol. Struct., 27, pp. 1139-1553. https://doi.org/10.1016/0020-7683(91)90115-V

[15] Lynch, C.S., Hwang, S.C., McMeeking, R.M., (1995). Micromechanical theory of the nonlinear behavior of ferroelectric ceramics. Proc SPIE; 2427:300-12 http://dx.doi.org/10.1117/12.200926

[16] Prewo, K.M., (1986). Tension and flexural strength of silicon carbide fibrereinforced glass ceramics. J Mater Sci, 21(3), pp.590-600 https://link.springer.com/article/10.1007/BF02403007

[17] Bruno, G., Efremov, A.M., Levandovsky, A.N., Clausen, B., (2011) Connecting the macro and microscopic strain response in porous ceramics: modeling and experimental validation. J Mater Sci., 46(1), pp. 61-73. https://link.springer.com/article/10.1007/s10853-010-4899-0

[18] Pozdnyakova, I., Bruno, G., Efremov, A.M., Clausen, B., Hughes, D.J., (2009) Stress dependent elastic properties of porous cellular ceramics Adv Eng Mater., 11, 1023-9. https://doi.org/10.1002/adem.200900192

[19] Ghassemi-Kakroudi, M., Huger, M., Gault, C., Chotard, T., (2009). Damage evaluation of two alumina refractory castables. J. Eur. Ceram. Soc., 29, 2211-8 https://doi.org/10.1016/j.jeurceramsoc.2008.12.019

[20] Turon -Vinas, M., Anglada, M., (2018) Dental Materials, 34(30), pp. 365375. https://doi.org/10.1016/j.dental.2017.12.007

[21] Dar, U.A., Gao, G., Wang, Y., (2019) Ceram. Int. 45(6), pp. 7931-7944. https://doi.org/10.1016/j.ceramint.2019.01.106

[22] Garcia-Fernandez, C.C., Gonzalez-Nicieza, C., Alvarez-Fernandez, M.I., Gutierrez-Moizant, R.A., (2018) Analytical and experimental study of failure onset during a Brazilian test. International Journal of Rock Mechanics and Mining Sciences, 103, pp. 254-265. https://doi.org/10.1016/j.ijrmms.2018.01.045
[23] Sheikh, M. Z., Wang Z., Du, B., et al., (2019) Ceram. Int., 45, pp. 79317944. https://doi.org/10.1016/j.ceramint.2019.01.106

[24] Sevostyanova, I.N., Sablina, T.Yu., Gorbatenko, V.V., Kulkov, S. N., (2019) Strain Localization during Diametral Compression of $\mathrm{ZrO}_{2}\left(\mathrm{Y}_{2} \mathrm{O}_{3}\right)$ Ceramics. Technical Physics Letters, 45(9), pp. 943-946. https://doi.org/10.1134/S1063785019090281

[25] Li, D., Wong, L.N.Y., (2003) Rock Mech. Rock Eng., 46, pp. 269-287. https://doi.org/10.1007/s00603-012-0257-7

[26] Mousavi Nezhad, M., Fisher, Q.J., Gironacci, E., et al., (2018) Rock Mech. Rock Eng., 51, pp. 1755-1775. https://doi.org/10.1007/s00603-018-1429-x

[27] Goltsev, V.Yu., Osintsev, A.V., Plotnikov A.S., (2017) Application of a disk specimen loaded according to the "Brazilian test" for evaluating the brittle strength of materials of non-geological origin. Letters on materials, 7(1), pp. 21-25. https://doi.org/10.22226/2410-3535-2017-1-21-25

[28] Kulkov, S.N., Smolin, I.Yu., Mikushina, V.A., Sablina, T.Yu., Sevostyanova, I.N., Gorbatenko, V.V., (2020) Studying Strain Localization in Brittle Materials during the Brazilian Test. Russian Physics Journal, 63, pp. 976983. https://doi.org/10.1007/s11182-020-02126-z

[29] Gregg S.J., Sing K.S.W., (1982) Adsorption, Surface Area and Porosity, 2nd ed., ACADEMIC PRESS, 304 p.

[30] Saltykov, S.A., (1976) Stereometricheskaya metallografiya [Stereometric metallography]. Moscow, Metallurgiya, 270 p.

[31] Scherrer, P., (1918) Bestimmung der Größe und der inneren Struktur von Kolloidteilchen mittels Röntgenstrahlen. Göttinger Nachrichten Gesellschaft, 2, pp. 98- 101.

[32] Stokes, A.R., Wilson, A.J.C., (1944) The diffraction of X rays by distorted crystal aggregates Proceedings of the Physical Society, pp. 174-181.

[33] Timoshenko, S.P., Goodier, J.N., (1951) Theory of Elasticity, OCR. Second Edition. - McGraw-Hill book company, Inc., 506 pp.

[34] Hertzberg, R.W., (1977) Deformation and Fracture Mechanics of Engineering Materials. John Wiley and Sons Ltd, London, 605 pp.

$\underline{\text { Ref.: }}$

Sevostianova, Irina N. - Sablina, Tatiana Yu. - Kulkov, Sergei N. Tihtih, Mohammed - Gömze, László A.: Stress-strain behavior of high porous zirconia ceramic

Építőanyag - Journal of Silicate Based and Composite Materials, Vol. 73, No. 4 (2021), 154-159. p. https://doi.org/10.14382/epitoanyag-jsbcm.2021.23

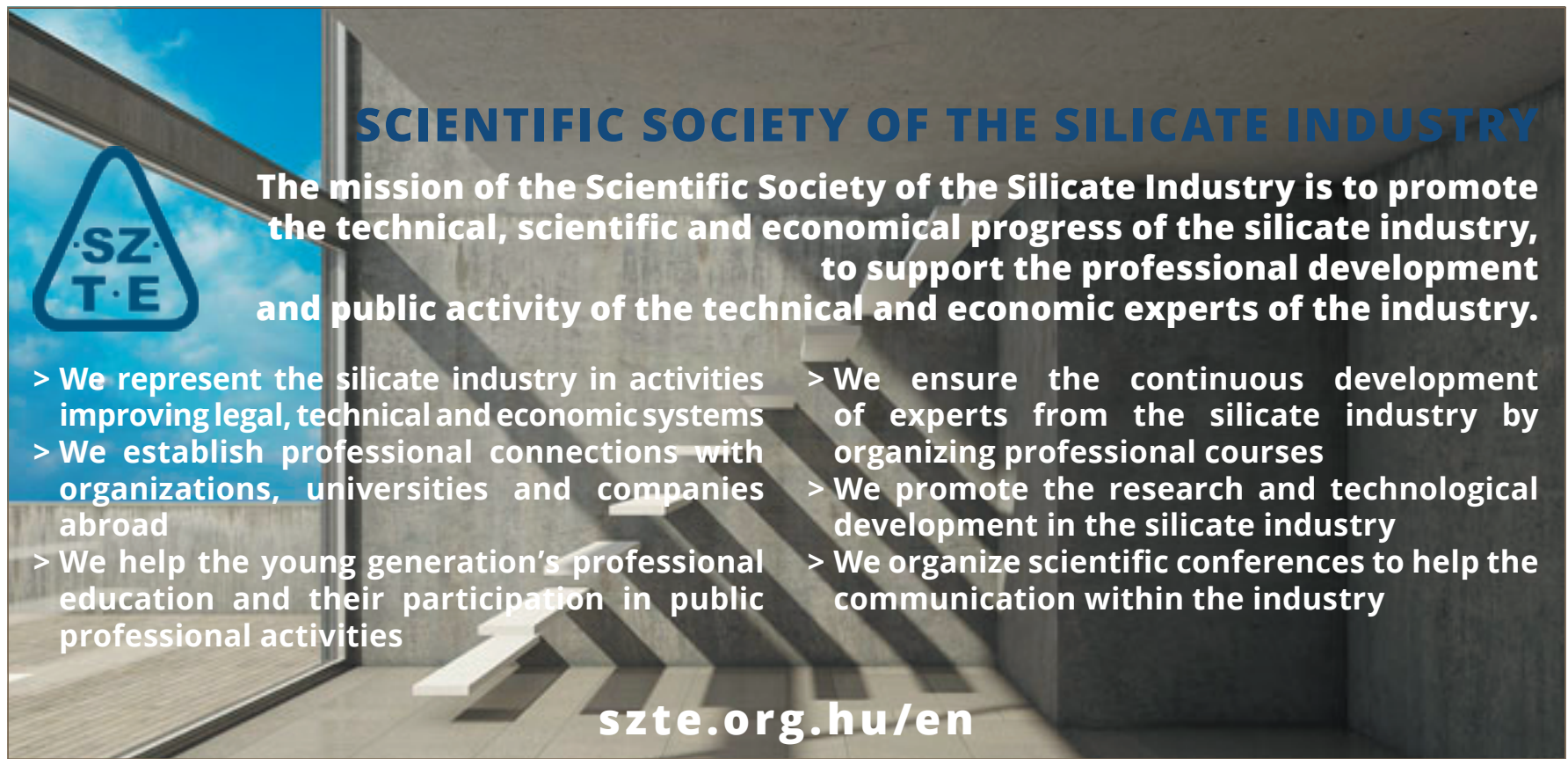

